\title{
Endocrine regulation of calcium and phosphorus concentration in camel's milk.
}

\author{
F Riad 1, M Ben Goumi 2, JC Tressol 3, MJ Davicco 3, V Coxam ' ${ }^{3}$, JP Barlet ${ }^{3}$ \\ 'Département de Biologie, Université Hassan II, Casablanca ; ¿IAV Hassan II, \\ Rabat, Maroc ; ${ }^{3}$ NRA, Theix, France
}

Some qualitative aspects of the milk of the dromedary suggest that the ability to produce milk of high nutritive value for offspring or for human beings during long periods of drought is important when evaluating the role of this animal in arid areas (Yagil \& Etzion, 1980, J Dairy Res, 47, 159-66). The regulation of mineral composition of camel's milk is unknown. Parathyroid hormone (PTH), although playing a major role in the regulation of plasma calcium ( $\mathrm{Ca}$ ) and inorganic phosphorus (Pi) plasma concentrations, does not seem essential for lactation-associated bone mineral mobilization (Hodnett DW et al, 1992, Am J Physiol, 262, E230-3). On the opposite, PTH-related peptide (PTHrP), secreted by the lactating caprine (Ratcliffe WA et al, 1992, J Endocrinol, 133, 87-93) and bovine (Barlet JP et al, 1993, Acta Endocrinol, 129, 332-6) mammary gland, increases milk $\mathrm{Ca}$ and $\mathrm{Pi}$ concentrations (Barlet JP et al, 1992, J Endocrinol, 132, 353-9). Thus, we have studied the influence of PTH and PTHrP on $\mathrm{Ca}$ and $\mathrm{Pi}$ concentration in camel's milk.

At the Research Station of Laayoune (Morocco), synthetic human PTH (1-34) and $\mathrm{PTHrP}(1-34)$ fragments dissolved in sterile saline were given $(4 \mathrm{nmol} / \mathrm{kg}$ body wt, at $9 \mathrm{am}$, for $1 \mathrm{~h}$ iv infusion) to 2 groups of 4 lactating camels during the 2nd month after parturition. A 3 rd (control) group received solvent $(50 \mathrm{ml})$ alone. After oxytocin injection ( $5 \times 6 \mathrm{IU} / \mathrm{animal})$ each camel was hand milked at 8,9 , and 10 am and at 1 and $3 \mathrm{pm}$. Milk collected at each milking was measured and a sample collected. Blood samples were simultaneously collected by jugular puncture. In plasma and milk samples $\mathrm{Ca}$ was measured by atomic absorption spectrophotometry and $\mathrm{Pi}$ by colorimetry.

Both PTH and PTHrP increased plasma $\mathrm{Ca}$ and decreased plasma $\mathrm{Pi}$, while no change was simultaneously demonstrated in controls. During the week before the experiment, the mean daily milk production for these 12 animals was $3.8 \pm 0.9$ । (mean \pm SEM). Milk production and $\mathrm{Ca}$ and $\mathrm{Pi}$ concentrations in milk from camels treated with PTH were never different from that measured in controls. On the opposite, in PTHrP-treated camels, milk $\mathrm{Ca}$ and $\mathrm{Pi}$ concentrations $(\mathrm{g} / \mathrm{l})$ increased from $0.93 \pm 0.03$ and $0.79 \pm 0.03$ before treatment to $1.35 \pm 0.15(\mathrm{P}<0.05)$ and to $1.21 \pm 0.05$ $(P<0.05)$ at the end of the infusion, respectively. Although milk production was unchanged, mammary $\mathrm{Ca}$ and $\mathrm{Pi}$ secretions $(\mathrm{mg} / \mathrm{h})$ increased from $583 \pm 93$ and $488 \pm 64$ before treatment to $1015 \pm 154(P<0.05)$ and to $926 \pm 16(P<0.05)$ during infusion, respectively. This demonstrates that in lactating camels, as in other domestic ruminants, exogenous PTHrP transiently but significantly increases mammary $\mathrm{Ca}$ and $\mathrm{Pi}$ secretion, while PTH does not influence milk mineral composition. 